\title{
Efikasi Pestisida Hayati pada Padi Varietas Tahan Tungro
}

\author{
Arif Muazam ${ }^{1)}$ dan Nurkholish Nugroho ${ }^{1)}$ \\ ${ }^{1}$ Tungro Disease Research Station Lanrang Sidrap South Sulawesi, Bulo Road 101 \\ ${ }^{2}$ Indonesian Center for Rice Research, Road Raya 9, Sukamandi, Subang, West Java \\ Email : azamsp84@yahoo.com
}

Diterima 20 Maret 2020; layak diterbitkan 30 Juni 2020

\begin{abstract}
Ringkasan
Sidrap sebagai sentra lumbung padi di Sulawesi Selatan, berperan aktif dalam upaya swasembada pangan Indonesia bagian timur secara khusus dan NKRI pada umumnya. Upaya budidaya tanaman padi terpadu telah dilaksanakan sebagai upaya meraih kemandirian pangan nasional. Makalah ini bertujuan membahas kepadatan populasi wereng hijau, serangga predator, dan hama lain pada pertanaman padi Inpari 36 sebagai varietas tahan tungro (new released) di daerah endemis lanrang. Penelitian dilaksanakan dilahan kebun percobaan Loka penelitian Penyakit Tungro, menggunakan Rancangan Acak Lengkap (RAL) 2 plot petakan petanaman varietas ukuran 10 x $10 \mathrm{~m} 2$ dengan 4 ulangan. Hasil penelitian menunjukkan secara umum wereng hijau (Nephotetic verescens) dewasa paling banyak pada varietas Inpari 36 tanpa perlakuan bioprotector. Predator alami yang ditemui berfluktuatif setiap minggu pengamatan yang mendominasi yaitu: Agriocnemis spp, Micraspis sp, Conocephalus longipennis, Araenus inustus, Lycosa pseudoannulata, Oxyopes javanacus,dan Tetraghenata maxilosa. Sedang pada 6-7 MST (minggu setelah tanam) muncul species Ophionea nigrofasciata dan pada 7MST ada species Anaxipa longipennis. Kesimpulan penelitian bahwa Perlakuan Bioprotektor secara umum menekan jumlah nimfa maupun imago wereng hijau namun tidak mematikan predator maupun parasitoid. Inpari 36 memiliki ketahanan yang baik terhadap serangan serangga hama pada umumnya dan wereng hijau pada khususnya. Jumlah Parasitoid paling banyak pada pekan ke-3 dari jenis Braconidae.
\end{abstract}

Kata kunci: Bioprotektor, Varietas Tahan Tungro, Inpari 36, Endemis .

\begin{abstract}
Sidrap as the center of rice granaries in South Sulawesi, plays an active role in efforts to self-sufficient in food in eastern Indonesia in particular and the Republic of Indonesia in general. Integrated rice cultivation efforts have been carried out as an effort to achieve national food independence. This paper aims to discuss the population density of green leafhoppers, predatory insects, and other pests on Inpari 36 rice as a tungro resistant variety (new released) in lanrang endemic areas. The research was carried out in the experimental garden of the Tungro Disease Research Center, using a completely randomized design (CRD) 2 plots of planting varieties measuring $10 \times 10 \mathrm{~m} 2$ with 4 replications. The results showed that in general, the green leafhopper (Nephotetic verescens) was most abundant in the Inpari 36 variety without bioprotector treatment. The natural predators encountered fluctuate every week of observation that dominates: Agriocnemis spp, Micraspis sp, Conocephalus longipennis, Araenus inustus, Lycosa pseudoannulata, Oxyopes javanacus, and Tetraghenata maxilosa. Meanwhile at 6-7 WST (weeks after planting) Ophionea nigrofasciata species appeared and at 7MST there was Anaxipa longipennis species. The conclusion of the study was that Bioprotector Treatment generally suppressed the number of green leafhopper nymphs and imagos but did not kill predators or parasitoids. Inpari 36 has good resistance to insect pests in general and green leafhoppers in particular. The highest number of parasitoids was in the 3rd week of the Braconidae species.
\end{abstract}

Keywords: Bioprotector, Resistant Varieties, Inpari 36, Endemic. 


\section{PENDAHULUAN}

Bioprotektor adalah usaha untuk menekan pemanfaatan pestisida sintetis yang berkembang pesat. Sejak tahun 2002 tercatat ada 813 nama dagang pestisida yang terdaftar untuk dipasarkan di Indonesia. dalam masa 10 tahun menjadi 2810 kemudian tahun 2016 kembali meningkat menjadi 3207. Banyak kerugian yang ditimbulkan dari penggunaan pestisida sintetis. Pencemaran dan kerusakan ekosistem pencemaran air, udara dan lahan pertanian selain menyebabkan predator musuh alami mati, resistensi hama, bahkan juga menyebabkan keracunan manusia [1]. Penggunaan insektisida sering tidak efektif karena penularan virus tungro oleh vektor berlangsung dalam jangka waktu yang pendek dan terjadi pergerakan vektor dari pertanaman sekitar secara terus-menerus [2]. Pada tahun 2001- 2005 kasus keracunan pestisida di Indonesia cukup tinggi yaitu dari 4.867 kasus sebanyak 3.789 orang meninggal [3]. Badan kesehatan dunia (World Health Organization) menyampaikan setidaknya sekitar 1-5 juta kasus keracunan pestisida kimia dengan kematian 220 ribu manusia. Permasalahan tersebut harus diatasi sedini mungkin, dengan penggunaan biopestisida hayati atau nabati yang ramah lingkungan. Hal ini berpotensi luas di Indonesia karena beraneka ragam tanaman dan bahan bio-degradable yang dapat dimanfaatkan dan aman untuk manusia karena tidak menimbulkan residu pada makanan yang dikonsumsi. Banyak keunggulan biopestisida nabati, yaitu mampu menekan keinginan makan serangga (anti feedding), repellent menolak makan, bahkan ada senyawa tanaman yang mampu mematikan serangga, selain itu dapat digunakan sebagai fungisida, bakterisida, dan herbisida karena memiliki allelopati.

Berdasarkan data Ditjen Tanaman Pangan yang diolah dari hasil pengamatan pihak internal maupun petugas Pengendali Organisme Pengganggu Tumbuhan (POPT) di daerah, total luas tanah yang terserang hama wereng dari Januari hinggal Juli 2017 mencapai 67.749 hektar. Sementara, lahan puso (gagal panen) yang diakibatkan wereng seluas 746,71 hektar [4].

Wereng hijau sebagai serangga vector penyebaran penyakit tungro, merupakan salah satu kendala penghambat produksi padi [5]. Wereng hijau menyerang padi secara langsung dengan cara mengisap cairan tanaman dan secara tidak langsung berperan sebagai penular (vector) virus tungro. Interaksi antara wereng hijau, virus tungro dan tanaman padi akan menimbulkan penyakit tungro yang merupakan penyakit terpenting pada padi yang disebabkan oleh virus [2]. Ditengah kondisi iklim yang tidak menentu, potensi cekaman penyakit terhadap usaha peningkatan produksi padi sewaktu-waktu dapat terjadi.

Produksi padi mengalami peningkatan. Dalam periode 1997-2000 dengan laju pertumbuhan rata-rata $1,67 \%$ per tahun, terutama karena bertambahnya areal panen [6]. Produksi padi tahun 2015 sebanyak 75,40 juta ton gabah kering giling (GKG) atau mengalami kenaikan sebanyak 4,55 juta ton $(6,42$ persen $)$ dibandingkan tahun 2014 [7]. Pencapaian ini telah 
mengantar Indonesia kembali meraih swasembada beras.

$$
\text { Propinsi Sulawesi Selatan }
$$

sebagai daerah penghasil tanaman pangan terbesar di kawasan Indonesia Timur, mendapat perhatian pemerintah dengan program Surplus Beras Dua Juta Ton dan Surplus Jagung 1,5 jut ton [8]. Daerah ini memiliki sumberdaya lahan dan iklim yang sangat bervariasi. Keragaman sumberdaya lahan dan iklim merupakan potensi untuk memproduksi komoditas pertanian unggulan di masing-masing wilayah sesuai kondisi agroekosistemnya.

Berdasarkan data dari Proteksi

Tanaman Pangan dan Hortikultura (BPTPH) Dinas Pertanian Sumatera Utara, serangan tungro pada tanaman padi tahun 2014 berkisar 67,3 hektare. Dengan tingkat serangan ringan sekitar 66,5 hektare dan sedang 0,8 hektare. Populasi wereng hijau dan serangga lain tidak dapat dipisahkan dari kejadian serangan virus tungro. Serangan tungro pada pertanaman padi mencapai lebih dari 200 ribu ha dengan nilai kerugian US\$ 100.000 terjadi pada tahun 19771995. Luas serangan tungro terus berkembang sejalan dengan upaya pengendalin penyakit yang gencar dilakukan [9]. Serangan tungro bukan baru saja di temukan pada tanaman padi, namun penyakit ini telah menghantui petani di seluruh tanah air [10]. Di daerah Sumatera Barat luas serangan 168,42 hektare dengan serangan ringan sampai sedang dan 59.34 hektar berat sehingga total kerugian mencapai 1,7 Milyar [11].

$$
\text { Penggunaan bioprotektor }
$$

menyebabkan vigor tanaman padi menjadi meningkat sehingga mampu mempertahankan diri dari gangguan
OPT (Organisme Pengganggu

Tanaman), termasuk wereng yang pada masa awal pertanaman menyerang hampir seluruh areal tanam padi di Kabupaten Purbalingga dan sekitarnya [12].

Badan Litbang Pertanian telah melepas beberapa varietas unggul baru di lahan sawah dengan potensi hasil 6,0 - 10 ton/hektar, salah satunya adalah Inpari 36 [13]. Inpari yang merupakan singkatan dari Inbrida Padi Sawah Irigasi adalah padi hinbrida yang ditanam di lahan sawah. Inbrida mempunyai arti varietas yang dikembangkan dari satu tanaman melalui penyerbukan sendiri sehingga memiliki tingkat kemurnian atau homozigositas yang tinggi. Varietas Inpari 36 tahan terhadap penyakit tungro [14]. Penyakit tungro disebabkan oleh hama wereng hijau yang membawa virus bentuk batang Rice Tungro Baciliform Virus (RTBV) dan bentuk bulat Rice Tungro Spherical Virus (RTSV) [15]. Pada kondisi normal varietas Inpari 36 memiliki panjang malai lebih dibanding varietas lainnya Inpari 42, Inpari 43 dan Inpari Blast. Jumlah gabah per malai inpari 36 yaitu 185.13. Inpari 36 memiliki tanggapan terbaik dilihat dari variabel panjang malai, persentase gabah hampa dan bobot 1000 butir [13].

Penelitian ini akan membahas mengenai hubungan kepadatan serangga wereng hijau sebagai vektor penyakit tungro dan serangga lainnya pada Varietas Padi Inpari 36 Tahan Virus Tungro yang diberi perlakuan Bioprotektor dan Kontrol didaerah endemis tungro lanrang, Sidenreng Rappang Sulawesi Selatan. 


\section{METODE PENELITIAN}

\section{a. Materi}

Penelitian dilaksanakan pada bulan April-Oktober 2017 bertempat di Kebun Percobaan Loka Penelitian Penyakit Tungro Lanrang Sidrap Sulawesi Selatan.

\section{b. Metode}

Rancangan yang digunakan Rancangan Acak Lengkap, dengan materi perlakuan yaitu Inpari 36 sebanyak 2 plot dengan 4 ulangan ukuran masing-masing $100 \mathrm{~m}^{2}$. Setiap pekan mulai pekan ke-2 setelah tanam sampai pekan ke-5 dilakukan pengambilan sampel data pengamatan. Caranya yaitu: menggunakan sweepnet 10 ayunan ganda menyilang ditengah petak, kemudian serangga yang tertangkap dimasukkan plastik kemudian dihitung jumlah wereng hijau, nimfa, dan predator, data dikumpulkan di tabel pengamatan, dihitung pula kejadian tungro di petak tanaman. Pemeliharaan dengan pemupukan Urea $300 \mathrm{~kg} / \mathrm{ha}$, Ponska $100 \mathrm{~kg} / \mathrm{ha}$ yang diberikan saat tanam dan sepertiga bagian urea diberikan satu minggu setelah tanam, selebihnya pada 45 hari setelah tanam atau mengikuti rekomendasi setempat. Hama dan penyakit dikendalikan dengan perlakuan Bioprotektor.

\section{c. Analisis data}

Data yang diperoleh dianalisis dengan anova analisis ragam dengan $\mathrm{Uji}$ F pada taraf kepercayaan $95 \%$, jika beda nyata dilanjutkan dengan uji lanjut Duncan menggunakan SPSS 16.0 [16].

\section{HASIL DAN PEMBAHASAN}

\section{a. Kepadatan Wereng hijau} Imago (Nephotetic verescens)

Populasi kepadatan wereng hijau pada pengamatan pertama (2MST) seperti terlihat pada Gambar 1.

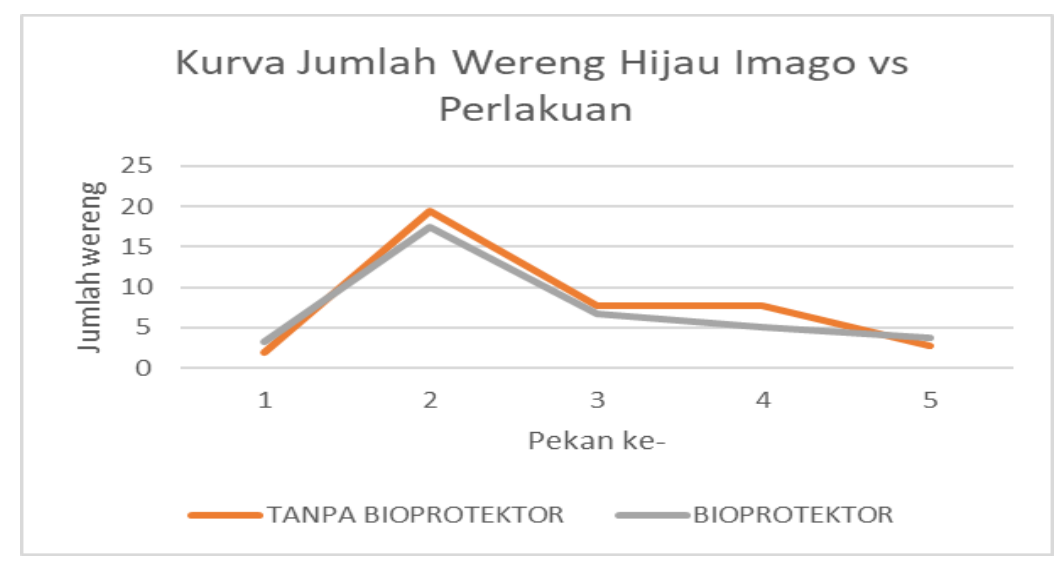

Gambar 1. Kurva Jumlah Wereng Hijau Imago vs Perlakuan

Wereng hijau merupakan salah satu hama utama yang sering menyebabkan kerusakan pada tanaman padi, karena hama tersebut dapat menularkan (vektor) penyakit tungro [17]. Kepadatan populasi wereng hijau beserta gejala tungro hasilnya bervariatif. Populasi wereng hijau dewasa lebih tinggi pada perlakuan tanpa bioprotektor rerata sebanyak 19,5 ekor dibandingkan populasi imago pada pekan (2MST) yang diberi perlakuan bioprotektor reratanya sebanyak 17,5 
ekor. Populasi wereng hijau menurun pada pengamatan ke-2 (3MST) kemudian kembali tinggi pada pengamatan ke-3 (4MST) sampai pengamatan ke-4 (5MST). Secara umum perlakuaan tanaman dengan bioprotektor jumlah wereng hijau lebih sedikit, Bioprotektor yang diaplikasikan nyata mampu menekan jumlah wereng hijau. Adapun jumlah wereng hijau pada akhir pengamatan semakin sedikit karena umur tanaman sudah pada fase dewasa.

Wereng hijau (Nephotetic verescens) imago sudah mulai muncul 2 minggu setelah tanam dan kepadatannya berfluktuasi dari minggu ke minggu sehingga terbentuk puncak kepadatan populasi pada 2 minggu setelah tanam, sedangkan nimfa paling banyak pada 5 MST.

Hasil ini sama dengan yang dilaporkan [18] bahwa Kepadatan populasi wereng hijau sangat rendah pada 1 dan 3 MST, sedangkan pada 5 hingga 7 MST populasi wereng hijau meningkat. Populasi wereng hijau juga akan mempengaruhi intensitas serangan tungro. Serangga tungro mulai ditemukan pada umur tanaman padi 1 minggu dan mulai meningkat pada umur 3 hingga 5 MST.

\section{b. Kepadatan Nimfa wereng hijau (Nephotetic verescens)}

Kurva Jumlah Nimfa Wereng Hijau dengan Perlakuan Bioprotektor dan tanpa Bioprotektor disajikan pada Gambar 2. Kurva Jumlah Nimfa Wereng Hijau hampir sama dengan pola wereng hijau fase dewasa, namun ada perbedaan jumlah peningkatan nimfa pada pengamatan ke-2 (3MST) dan semakin banyak sampai pekan ke 5 . Wereng Hijau dewasa sudah bertelur dipelepah daun, meski imago sudah banyak yang mati namun nimfanya terselamatkan sehingga populasi masih banyak. Tanaman yang diberi perlakuan bioprotektor jumlah nimfanya lebih sedikit dari pada tanaman yang tidak diberi perlakuan bioprotektor (Gambar 2).

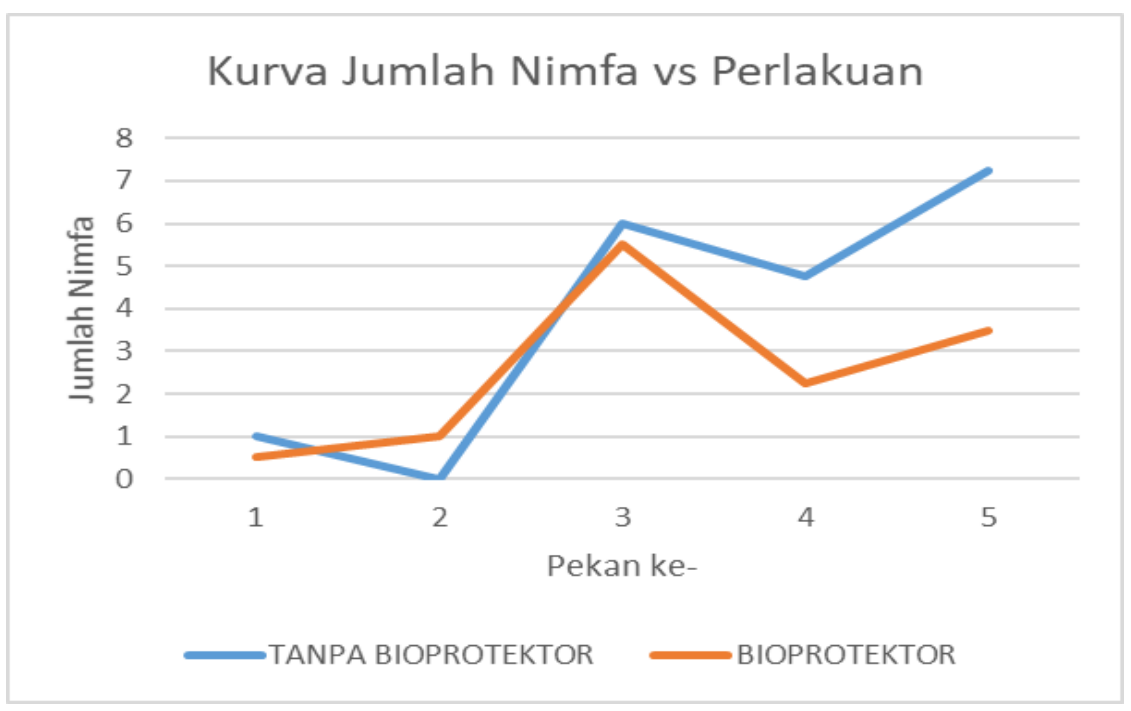

Gambar 2. Kurva Jumlah Nimfa Wereng Hijau dengan Perlakuan Bioprotektor dan tanpa Bioprotektor 
Berdasarkan hasil pengujian Anova diperoleh hasil bahwa rerata jumlah Imago pada perlakuan bioprotektor maupun kontrol diperoleh hasil yang tidak signifikan dari $\mathrm{F}$ hitung sebesar: 0,03 dan F Tabel sebesar 5,17

\section{c. Kepadatan predator wereng hijau (Nephotetic verescens) dan hama lain}

Perlakuan bioprotektor ternyata seolah-olah mempengaruhi jumlah predator yang ada di lahan pertanaman, meski dalam teori biopredator tidak mematikan predator hama, sebagaimana dalam Gambar 3 karena predator rendah misalnya kumbang crisomelidae maka sehingga F Hit < FTabel, maka Ho ditolak. Begitu pula hasil rerata hitung pada Nimfa diperoleh hasil $F$ hitung sebesar 0,55 dan $F$ Tabel sebesar 5,17 sehingga $F$ hit $<$ F Tabel maka Ho di total.

hama ulat agak tinggi, namun tidak sampai ambang batas sehingga dari Gambar bioprotektor. Gambar 3, memberikan informasi bioprotektor aman digunakan untuk diaplikasi dilapangan karena tidak mematikan predator alami. Berdasarkan analisis varian dari beberapa waktu pengamatan, (Tabel 1) telihat dari varietas yang diujikan untuk wereng hijau stadia nimfa maupun imago tidak terdapat perbedaan yang nyata.

Tabel 1. Rerata Hasil Uji Bioprotektor Wereng Hijau Imago dan Nimfa

\begin{tabular}{ccccc}
\hline \multicolumn{3}{c}{ Imago } & \multicolumn{2}{c}{ Nimfa } \\
\hline Ulangan & $\begin{array}{c}\text { Tanpa } \\
\text { Bioprotektor }^{\mathrm{ns}}\end{array}$ & Bioprotektor $^{\mathrm{ns}}$ & $\begin{array}{c}\text { Tanpa } \\
\text { Bioprotektor }^{\mathrm{ns}}\end{array}$ & Bioprotektor $^{\mathrm{ns}}$ \\
\hline 1 & 2,00 & 3,25 & 1,00 & 0,50 \\
2 & 19,5 & 17,5 & 0,00 & 1,00 \\
3 & 7,75 & 6,75 & 6,00 & 5,50 \\
4 & 7,75 & 5,00 & 4,75 & 2,25 \\
5 & 2,75 & 3,75 & 7,25 & 3,50 \\
\hline
\end{tabular}

Keterangan: ${ }^{\mathrm{ns}}$ non signifikan

Intensitas serangan tungro dipengaruhi oleh stadia tanaman, ketahanan varietas, stadia sumber inokulum dan populasi wereng hijau infektif, Pada penelitian ini varietas yang digunakan merupakan varietas yang tahan dari serangan tungro [19]. Wereng hijau memiliki kemampuan memacar yang tinggi sehingga efektifitas menularkan virus tungro tinggi pada kondisi kepadatan populasi yang tinggi [20]. Sesuai dengan data pengamatan populasi wereng hijau pada pekan pengamatan, populasi cenderung rendah.

Hasil ini menunjukkan bahwasanya varietas Inpari 36 secara kualitas durabilitas ketahanan terhadap tungronya masih baik, ketahanan terhadap serangan hama lainpun sangat baik. 


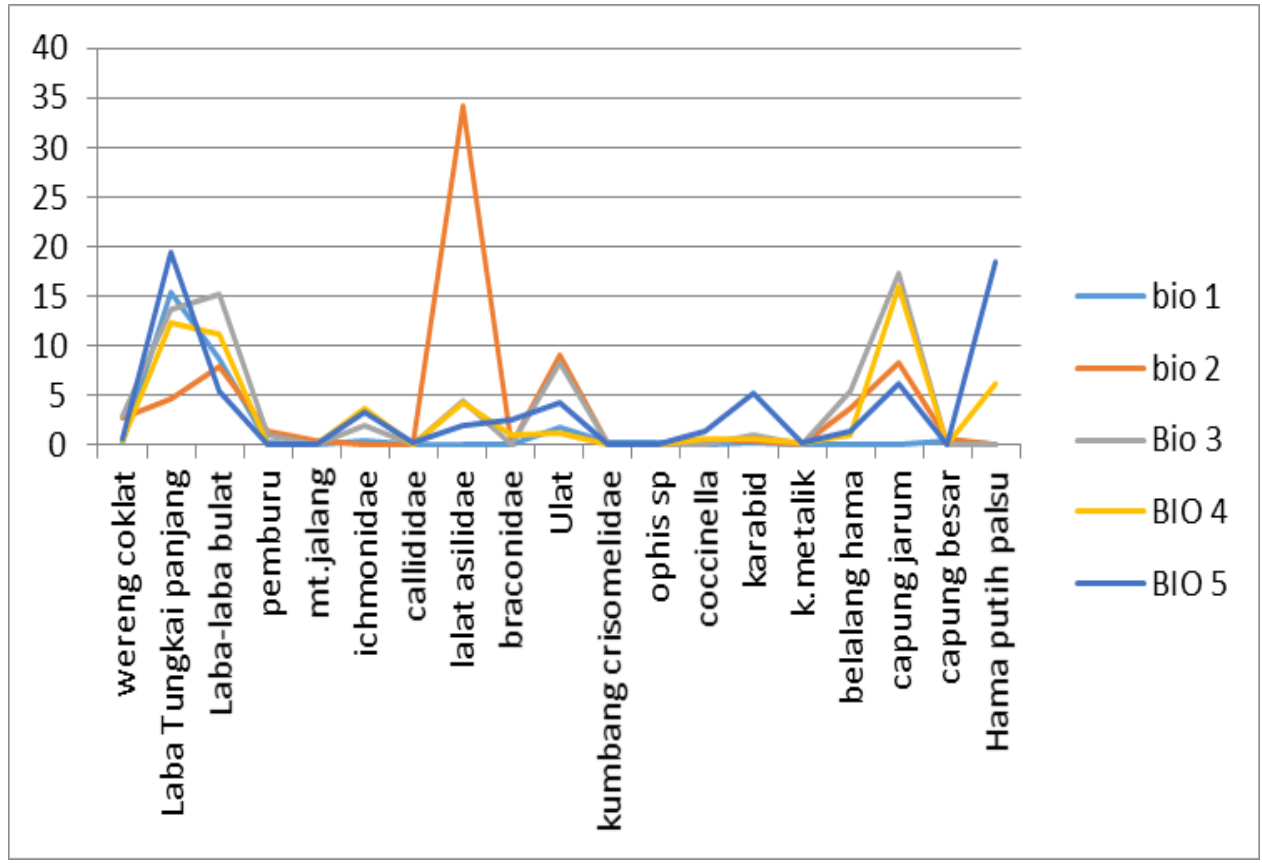

Gambar 3. Kepadatan Predator dan Hama lain pada 2 sd 5 MST Perlakuan Bioprotektor

\section{d. Kepadatan populasi predator dan Parasitoid di lahan pertanaman}

Kepadatan Predator dan Hama lain pada 2 sd 5 MST Kontrol disajikan pada Gambar 4. Dari Kontrol pada Gambar 4 dapat dilihat bahwa Jenis Parasitoid dan Predator hama sangat tinggi capaian jumlahnya sehingga hama tanaman padi jauh dibawah ambang, seperti hama putih palsu sangat sedikit ditemukan.

Populasi predator setiap minggu pengamatan tidak tetap atau mengalami fluktuatif. Ada 7 species predator yang mendominasi keberadaannya selama 5 minggu pengamatan yaitu: Agriocnemis spp, (Capung jarum), Micraspis sp, (kumbang kubah), Conocephalus longipennis (Belalang tungkai Panjang), Araenus inustus (laba-laba), Lycosa pseudoannulata (Laba-Laba Emas), Oxyopes javanacus (Laba-laba Bermata Jalang), dan Tetraghenata maxilosa (laba-laba). Sedang 5 MST ada species Anaxipa longipennis.
Predator paling banyak pada 2MST yaitu species Tetraghenata maxilosa. Predator 3MST yaitu species Tetraghenata maxilos, Araenus.. Predator paling banyak pada 4MST yaitu species Tetraghenata maxilos, Araenus inustus (Gambar 4).

Predator paling banyak pada 5MST yaitu species Tetraghenata maxilosa, sehingga korelasi dari Gambar 1 dan Tabel 1 dapat diketahui bahwa jumlah wereng hijau serta kejadian tungro teryata paling tinggi pada pekan ke-2 karena predatornya presentase sedikit. Secara umum parasitoid dan lalat asilidae paling banyak, laba-laba tungkai panjang, dan capung jarum. Keberadaan musuh alami ditemukan pada setiap minggu pengamatan walaupun kepadatan wereng hijau sangat rendah pada minggu tertentu, hal ini diduga karena kepadatan serangga hama lain seperti wereng coklat, 


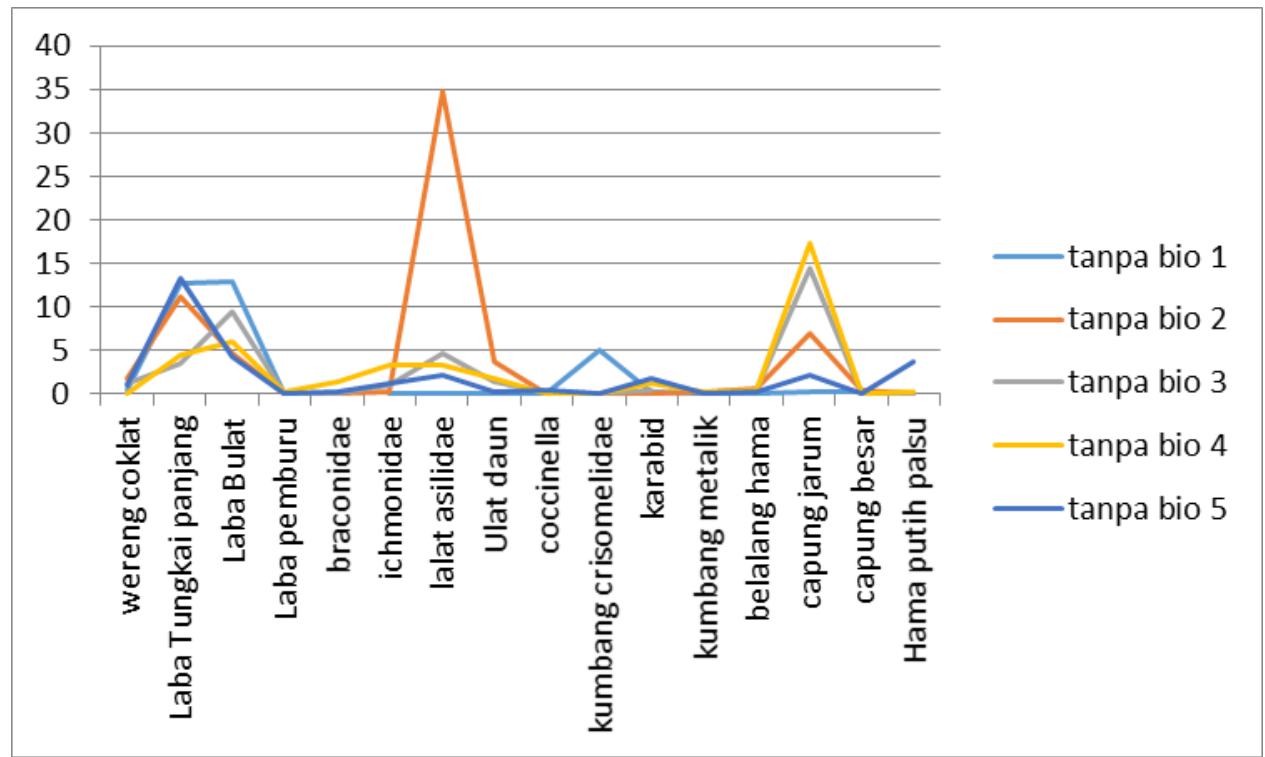

Gambar 4. Kepadatan Predator dan Hama lain pada 2 sd 5 MST Kontrol

\section{KESIMPULAN}

Tidak terdapat perbedaan Jumlah Nimfa Wereng Hijau dengan perlakuan Bioprotektor dan tanpa Bioprotektor. Perlakuan Bioprotektor secara umum menekan jumlah nimfa maupun imago wereng hijau namun tidak mematikan predator maupun parasitoid. Terdapat 7 species predator yang didominasi jenis laba-laba (Tetraghenata maxilosa, Araenus inustus, Lycosa pseudoannulata) dan capung jarum (Agriocnemis spp). Inpari 36 memiliki ketahanan yang baik terhadap serangan serangga hama pada umumnya dan wereng hijau pada khususnya. Jumlah Parasitoid paling banyak pada pekan ke3 dari jenis Braconidae.

\section{REFERENSI}

[1] M. F. . Singkoh and D. Y. Katili, "Bahaya Pestisida Sintetik
(Sosialisasi Dan Pelatihan Bagiwanita Kaum Ibu Desa Koka Kecamatan Tombulukabupaten Minahasa)," J. Peremp. dan Anak Indones., vol. 1, no. 1, pp. 5-12, 2019.

[2] Senoaji, W. Praptana, and R. Heru, "Perkembangan populasi wereng hijau dan predatornya pada beberapa varietas padi," $J$. Perlindungan Tanam. Indones., vol. 19, no. 1, pp. 65-72, 2015.

[3] Anonim b., "Pencegah Gagal Panen Penambah Tebal Kantong Petani," Agroinovasi Badan Litbang Pertanian Edisi 10 - 16 Juli 2019 No.3806 Tahun XLIX., no. 3806, p. 3806, 2019.

[4] K. Budi, "Pemerintah Gerak Cepat Hadapi Serangan Wereng Coklat," Artikel Kompas.com https://ekonomi.kompas.com/rea d/2017/08/12/203032726/pemeri ntah- gerak-cepat-hadapiserangan-wereng-coklat .[Diakses tanggal 16 Februari 
2020]., p. [Diakses tanggal 16 Februari 2020], 2017.

[5] D. Yuliati and I.N. Widiarta, "Pengendalian Penyakit Tungro Melalui Eliminasi Peran Vektor Wereng Hijau Dengan Pengendalian Ramah Lingkungan," AGRIC, vol. 29, no. 2, pp. 77-88, 2019.

[6] Anonim, "Peningkatan Produksi Padi Menuju 2020," http://pangan.litbang.pertanian.g o.id/ repositori-20.html. [Diakses tanggal 7 januari 2018]., vol. 3, no. 2017, 2014.

[7] BPS, "Berita Resmi Statistik," Berita Resmi Statistik No. 62/07/Th. XIX, O1 Juli 2016 No. 62/07/ Th. XIX, 01 Juli 2016, p. 01 Juli 2016, 2016.

[8] Herniawati and S. Kadir, "Potensi Iklim, Sumber Daya Lahan, dan Pola Tanam di Sulawesi Selatan Prosiding Seminar Nasional Serealia:," in Prosiding Seminar Nasional Serealia, 2009, pp. 1-7.

[9] Muhsin, "DNA Mirip Virus Batang Tungro Ditemukan dalam Genom tanaman Padi 30(5): 16.," War. Penelitin dan Pengemb. Pertanian., vol. 30, no. 5, p. 16, 2008.

[10] Anonim, "Profit Jutaan Rupiah Dari Sawah Tadah Hujan," http://www.medanbisnisdaily. com/news/read/2015/08/31/1835 54/profit-jutaan-rupiah-darilahan- tadah-hujan/. [Diakses tanggal 18 Desember 2019]., vol. 52, no. 1, pp. 1-5, 2015.

[11] Anonim, "Serangan Tungro sampai juni 2015," iperta.sumbarprov.go.id/downlot. php?file. .Jun\%202015., p. [Di akses tanggal 9 Juli 2015]., 2015.

[12] S. Dyah, "Integrasi Teknologi UNSOED - Badan Litbang Pertanian Kementerian Pertanian, Harapan Baru Petani Untuk
Tetap Panen,"

http://unsoed.ac.id/id/berita/integ rasi-teknologi-unsoed-

\%E2\%80\%93- badan-litbangpertanian-kementerianpertanian-harapan-baru.

[Diakses, 2017.

[13] A. Jamil, P. Sasmita, Y. Baliadi, and A. Guswara, Deskripsi Varietas Unggul Baru Padi Badan Penelitian dan Pengembangan

Pertanian, Kementerian

Pertanian, Jakarta. Kementerian Pertanian, Jakarta., 2015.

[14] S. Bardono, "Varietas Inpari 36 Lanrang Primadona Di Tanah Mandar," http://technologyindonesia.com/pertanian-danpangan/inovasi-

pertanian/varietas-inpari-36lanrang-primadona-di-tanahmandar/, p. 16 Desember 2019, 2019.

[15] R. H. Praptana and M. Yasin, "Epidemiologi dan Strategi Pengendalian Penyakit Tungro," Iptek Tanam. Pangan, vol. 3, no. 2, pp. 184-204, 2008.

[16] Gomez and Gomez, Prosedur Statistik Untuk Penelitian Pertanian, Edisi kedu. Jakarta.: Penerbit Universitas Indonesia(UI-Press)., 2010.

[17] M. M. Kesek, J. Pelealu, N. N. Wanta, and J. M. E. Mamahit, "Populasi Hama Wereng Hijau (Nephotettix Spp.) dan Wereng Punggung Putih (Sogatella Furcifera Horv.) pada Tanaman Padi Sawah di Kecamatan Sonder Kabupaten Minahasa," Cocos, vol. 7, no. 1, pp. 1-14, 2015.

[18] D. Yuliani, I. N. Widiarta, and D. Kusdiaman, "Karakteristik Wereng Hijau dan Epidemi Tungro Di Kabupaten Garut, Provinsi Jawa Barat," urnal Pengkaj. dan Pengemb. Teknol. 
Jurnal RISET Agribisnis dan Peternakan

Vol. 5, No. 1, Juni 2020, Hal 30 - 38

ISSN 2527-9912

Efikasi Pestisida .....

Pertan., vol. 18, no. 1, pp. 43-56, 2015.

[19] R. H. Praptana and A. Burhanuddin, "Keseuaian Waktu Tanam dan Varietas dalam Pengendalian Penyakit Tungro di Sulawesi Barat," in Prosiding Seminar Ilmiah dan Pertemuan Tahunan PEI PFI XIX Komisariat Daerah Sulawesi
Selatan, 2008, no. November, p. 5 November 2008.

[20] I. N. Widiarta, "Wereng Hijau (Nephottetix virescens Distant): Dinamika Populasi dan Strategi Pengendalianya Sebagai Vektor Penyakit Tungro," J. Litbang Pertan., vol. 24, no. 3, p. 2005, 2005. 